\title{
DISZKONTÁLÁSI MODELLEK ÉS A HIPERBOLIKUS DISZKONTÁLÁS EREDMÉNYEINEK EGY LEHETSÉGES ALKALMAZÁSI TERÜLETE: A NYUGDÍJ- ELÖTAKARÉKOSSÁG
}

\author{
Nagy Sándor
}

\section{SUMMARY}

Nowadays the retirement planning (savings) has become an important issue as the sustainability of pension systems due to negative demographic trends has to face significant risks and threats. The lack of saving induces not only economic but also psychological deliberations and triggering motivations. In this paper I demonstrate such theoretical aspects of behavioral economics, which try to explore and measure the actors' self-control problems.

\section{BEVEZETÉS}

Életünk során folyton döntéseket hozunk, illetve válaszút elé kerülünk. A döntések meghozatalának időpontja és annak hatásai időben eltérhetnek egymástól, és a különböző idösíkbeli kimenetek, hasznosságok értékelése, a rájuk vonatkozó preferencia-szerkezet is számos különbözőséget mutathat. Az ilyen jellegü döntéseket intertemporális választásoknak nevezzük. Az idős korra való megtakarításokon keresztüli anyagi felkészülés szintén egy intertemporális döntés, amellyel szinte mindenkinek szembesülni kell: a mai időszak fogyasztásáról, hasznosságérzetéről lemondva $(t)$ egy későbbi időszak $\left(t_{n}\right)$ többletfogyasztásáért, többlethasznosságáért cserébe. A magatartás gazdaságtan (és azon belül a dinamikusan inkonzisztens viselkedés kérdésének vizsgálata), valamint a nyugdíjcélú megtakarítások igényének, kívánalmának logikai összekapcsolása sok szerzőt ${ }^{23}$ sarkallt a témakör vizsgálatára (Laibson 1996, 1998, Laibson et al. 1998, Samwick 1998, Normann-Langer 2001, Diamond-Köszegi 2003, SchwarzSheshinski 2006).

\section{A NEOKLASSZIKUS PREFERENCIA-RENDEZÉS}

A neoklasszikus felfogás szerint a gazdasági szereplők viselkedése racionális, Koltay és Vincze a racionális döntéshozatalt a következőképpen jellemzik (KoltayVincze 2009: 496):

- a gazdasági szereplök, fogyasztók, döntéshozók konzisztensek, ellentmondásmentes preferenciákkal rendelkeznek ${ }^{24}$, jellemző a statikus problématér, amelyben az időnek nincs szerepe (time consistency), a leszámítolási ráták az időben állandóak, a fogyasztók diszkontálási függvénye exponenciális (Lippai 2009: 690)

- az egyének minden esetben a számukra legmegfelelőbb helyzetet választják

\footnotetext{
${ }^{23}$ A felsorolás a teljesség igénye nélkül készült

${ }^{24}$ Lásd bövebben: Samuelson-Nordhaus: Közgazdaságtan, Aula Kiadó 16. kiadás 2008.
} 
- a külső környezet értékelésében csak az információk hiánya lehet gátló tényező

- az önös érdekek elötérbe helyezése, ugyanakkor a közösség jólétét kevésbé vagy egyáltalán nem tartja fontosnak

- a fogyasztói igények hosszú távon kielégíthetetlenek

- tökéletes matematikai analitikus képességek ${ }^{25}$

Abban az esetben, ha a fenti feltételrendszer alapján szeretnénk modellezni az intertemporális választók preferenciáit a fogyasztás szempontjából, akkor a Samuelson által bemutatott diszkontált hasznosság elméletét (Discounted Utility Model, DU) alkalmazhatjuk (Samuelson 1937).

(1) $U\left(\mathrm{x}_{1}, \mathrm{x}_{2}, \ldots \mathrm{x}_{\mathrm{t}}\right)=\sum_{t=1}^{T}\left(\frac{1}{1+\rho}\right)^{t} \mathrm{u}\left(\mathrm{x}_{\mathrm{t}}\right)$, ahol $\mathrm{U}$ az intertemporális hasznosság összértéke a , $t$ " periódusban; $\rho$ az időre vonatkoztatott preferencia ráta (konstans), továbbá $0<\left(\frac{1}{1+\rho}\right)<1$

$\mathrm{Az}$ egyenlet segítségével kiszámíthatjuk egy későbbi fogyasztás jelenbeli értékét, illetve a jelenből kiindulva optimalizálhatjuk a fogyasztási pályát (DezsőNeszveda 2010). Tulajdonképpen a modellben a jelenleg érzékelt hasznosság egyenlö a jövőbeni időszak pillanatnyi hasznosságainak súlyozott diszkontált összegével. A diszkontráta kiszámítása úgy történik, hogy megvizsgálják két időpont közötti hasznosságérzetek közömbösségét.

(2) $u\left(x_{1}\right)(1+\rho)^{t}=u\left(x_{2}\right)$

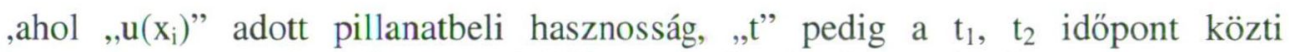
intervallum nagysága. Az egyenletből meghatározható az ,,$”$ diszkontráta értéke (van der Pol-Cairns 2002: 81). A normatív modell a fent vázolt (1) és (2) exponenciális diszkontálási formulát használja (Lippai 2009). Wahlund és Gunnarson az intertemporális diszkontfaktort helyettesítési határrátaként fogja fel a jelen és a jövőbeli fogyasztás között (Wahlund-Gunnarson 1996, Lippai 2009).

A felsorolást áttekintve joggal érződik, hogy ezek túlnyomó részben erösen hipotetikus jellegúek, és a valósághoz nem sok kapcsolódási pontjuk van. Hámori erről a következőképp ir ${ }^{26}$ : „...Az utóbbi néhány évben kísérletek és tereptanulmányok sokasága bizonyította, hogy az emberek meghatározott körülmények között szisztematikusan eltérnek a közgazdasági értelemben vett racionalitástól...”(Hámori 1998: 17).

\footnotetext{
${ }^{25} \mathrm{Az}$ utolsó három tulajdonságot a szerzőpáros kiegészítő feltevésként aposztrofálják (KoltayVincze 2009)

${ }^{26}$ Lippai mủvében is megtalálható az idézet (Lippai 2009)
} 


\section{A HIPERBOLIKUS DISZKONTÁLÁS}

Professzor Hámori szerint említett kísérletek és tereptanulmányok, amelyek a fogyasztói döntések, viselkedések anomáliáival foglalkoznak egészen az előző évszázad közepéig nyúlnak vissza. Robert Strotz volt az első szerző, aki a magatartásbeli - a racionális modelltől különböző - viselkedési eltérésekről publikált 1956-ban, és megállapításaiban az időben nem állandó diszkont rátát említi (Strotz 1956, Sanchez-Chavez 2008). Laibson a jelenséget a következöképp összegzi ${ }^{27}$ : a fogyasztóknak két véleménye, érzülete van az intertemporális döntéseket illetően. A jelenlegi és a jövöbeli preferenciák között egyfajta konfliktus, „preferencia-váltás” alakul ki, feltéve, hogy ezek a preferenciák dinamikusan inkonzisztensek. Például a jelenlegi értékítéletünk szempontjából nézve két távoli időpontbeli ( $t$ és $t+l$ ) hasznosságérzet $\left(\mathrm{u}(\mathrm{x})_{\mathrm{t}}\right.$ és $\left.\mathrm{u}(\mathrm{x})_{\mathrm{t}+1}\right)$ közötti diszkontráta hosszú távú és alacsony, míg a „t” időpont perspektívájából ugyanazt a viszonyt kifejező diszkontráta már rövid távú és magas lesz. A fenti összefüggést leginkább a hiperbolikus diszkontfüggvények írják le, amelyben a diszkontráták értéke monoton csökkenő (Laibson 1996, 1998). A hiperbolikus diszkontálás igazolását, alátámasztását számos pszichológus és közgazdász végezte számos laboratóriumi állat- és humánkísérletek, illetve empirikus bizonyítékok dokumentációjával. A téma ${ }^{28}$ szempontjából kiemelkedő, sokat idézett szerzők a következők: Phelps-Pollak (1968), Zeckhauser-Fels (1968), Peleg-Yaari (1973), Goldman (1980), Thaler-Shefrin (1981), Schelling (1984), Akerlof (1991), Ainslie (1992), Loewenstein-Prelec (1992), Laibson (1996), Angeletos et al. (2001), Noor (2009).

A hiperbolikus diszkontálás időpreferenciára vonatkozó rátája, ellentétben az exponenciális diszkontálás konstans rátájával, függ attól az időintervallumtól, ami a döntés pillanatától az eseményig tart. A továbbiakban ezt $\tau$-val jelölöm. A következőkben bemutatok négy ilyen elven müködő modellt, amelyet Pol és Cairns, valamint a kvázi-hiperbolikus diszkontálással foglalkozó irodalmak felhasználásával teszek meg (van der Pol-Cairns 2001). A legelső a sorban Loewenstein-Prelec ${ }^{29}$ modellje, amelyet „LP” rövidítéssel jelölök.

(3) $U_{\mathrm{LP}}\left(\mathrm{x}_{1}, \mathrm{x}_{2}, \ldots \mathrm{x}_{\mathrm{t}}\right)=\sum_{t=1}^{T}\left(\frac{1}{1+\alpha \tau}\right)^{\gamma / \alpha} \mathrm{u}\left(\mathrm{x}_{\mathrm{t}}\right)$, ahol $\alpha, \gamma>0$ itt az idő észlelési függvénye time_p $(\tau)=\gamma \ln (1+\alpha \tau) / \alpha \ln (1+\mathrm{r})$, az „,r” a pénzügyi modelleknél alkalmazott kamatráta ${ }^{30}$.

\footnotetext{
${ }^{27}$ Nem szó szerinti idézés, csupán összegzés Laibson $(1996,1998)$ írásaiból

${ }^{28}$ A hiperbolikus diszkontálás jelenségét kutatók, a felsorolás közel sem teljes

${ }^{29}$ Az általános hiperbolikus diszkontálás függvényének axiomatikus levezetését Loewenstein és Prelec alkotta meg 1992-ben.

${ }^{30}$ Itt pénzben kifejezett hasznosságról beszélhetünk, a kamatráta $(r)$ teremti meg a kapcsolatot a különböző időpontbeli pénzértékek között
} 
A diszkontráta $(1+\alpha \tau)^{-\gamma / \alpha}$ csökken, ha a $\tau$ kitolódik (az időintervallum kitolódik). A ,, ${ }^{\prime \prime}$ paraméter az idő sebességének az egyéni észlelését mutatja. Ha $\gamma=0$, akkor az egyén számára az idő végtelenül gyors, ellenkező esetben, amikor a $\gamma$ tart a végtelenhez, akkor az egyén nem érzékeli az időt. $\mathrm{Az}$, , $\alpha$ ” paraméter arról árulkodik, hogy a függvény mennyire tér el a tradicionális megközelítéstől. Amennyiben $\alpha=0$, akkor az exponenciális diszkontálási függvénynek megfelelően alakul (Lippai 2009: 4). A kétparaméteres LP-modellből további egyenletek származtathatóak, ha egyes paramétereket rögzítünk. Harvey (HRV) egyenlete a következő (Harvey 1986):

(4) $U_{\mathrm{HRV}}\left(\mathrm{x}_{1}, \mathrm{x}_{2}, \ldots \mathrm{x}_{\mathrm{t}}\right)=\sum_{t=1}^{T}\left(\frac{1}{1+\tau}\right)^{\gamma} \mathrm{u}\left(\mathrm{x}_{\mathrm{t}}\right)$, ahol $\alpha=1$, tehát teljesen hiperbolikus diszkontálási modellről beszélhetünk, ugyanakkor az idő érzékelésének a függvénye: time $\not p(\tau)=\gamma \ln (1+\tau) /(1+\mathrm{r})$

Mazur (MZR) elképzelése szerint az $\gamma / \alpha$ hányadosa pontosan egyenlő eggyel. Ilyenkor a diszkontált hasznosság egyenlete a következöképp írható fel (Mazur 1987):

(5) $U_{\mathrm{MZR}}\left(\mathrm{x}_{1}, \mathrm{x}_{2}, \ldots \mathrm{x}_{\mathrm{t}}\right)=\sum_{t=1}^{T}\left(\frac{1}{1+\alpha \tau}\right) \mathrm{u}\left(\mathrm{x}_{\mathrm{t}}\right)$, itt az idő érzékelési függvénye: time $\_p(\tau)=\ln (1+\alpha \tau) / \ln (1+\mathrm{r})$

A kvázi hiperbolikus (Q-HB) diszkontálási modell megalkotása Laibson nevéhez füződik (Laibson 1996):

(6) $U_{\mathrm{Q}-\mathrm{HB}}\left(\mathrm{x}_{1}, \mathrm{x}_{2}, \ldots \mathrm{x}_{\mathrm{t}}\right)=\beta \sum_{t=1}^{T}(\delta)^{i} \mathrm{u}\left(\mathrm{x}_{\mathrm{t}}\right)$, ahol $0<\beta \leq 1$; a diszkontfaktorok: $(1, \beta \delta$, $\left.\beta \delta^{2} \ldots \beta \delta^{\mathrm{i}}\right)$ Laibson feltételezése szerint az egyén jelen pillanatra vonatkozó hasznosságérzete egyenlő eggyel, míg a későbbi időpontra (i) értelmezve a helyettesítési határráta $\beta \delta^{\mathrm{i}}$, a diszkont függvény képe az első időszak után azonos meredekségü.

A kvázi hiperbolikus modellben a $\delta$ paraméter a hosszú távú preferenciákat fedi le, miközben a $\beta$ paraméter az azonnali kielégülést, hasznosságot vagy annak rövid távú mértékét jelzi. Ha a $\beta$ értéke alacsony, akkor az egyén több hangsúlyt fektet a jelenre. $\beta=1$ esetén a modell leegyszerüsödik a klasszikus változatra (SanchezChavez 2008). Annak érdekében, hogy kicsit szemléletesebb legyen a fenti mondanivaló egy ábra segítségével láthatóvá válik három diszkontálási modell diszkontfüggvényének grafikonja (exponenciális, hiperbolikus és kvázihiperbolikus). Az ábra szemléltetés céljából készült Laibson példája alapján. A vízszintes tengelyen az esemény kimenetéig, bekövetkeztéig hátralévő időtáv van megjelenítve, itt történetesen évek formájában; a függöleges tengelyen a diszkont függvények értéke (diszkontráták időtávtól függö értéke) látható, amire fennáll $0<$ diszkont faktor értéke $\leq 1$. 


\section{1. ábra: Diszkont függvények grafikonjai - Exponenciális, Hiperbolikus, Kvázi-hiperbolikus}

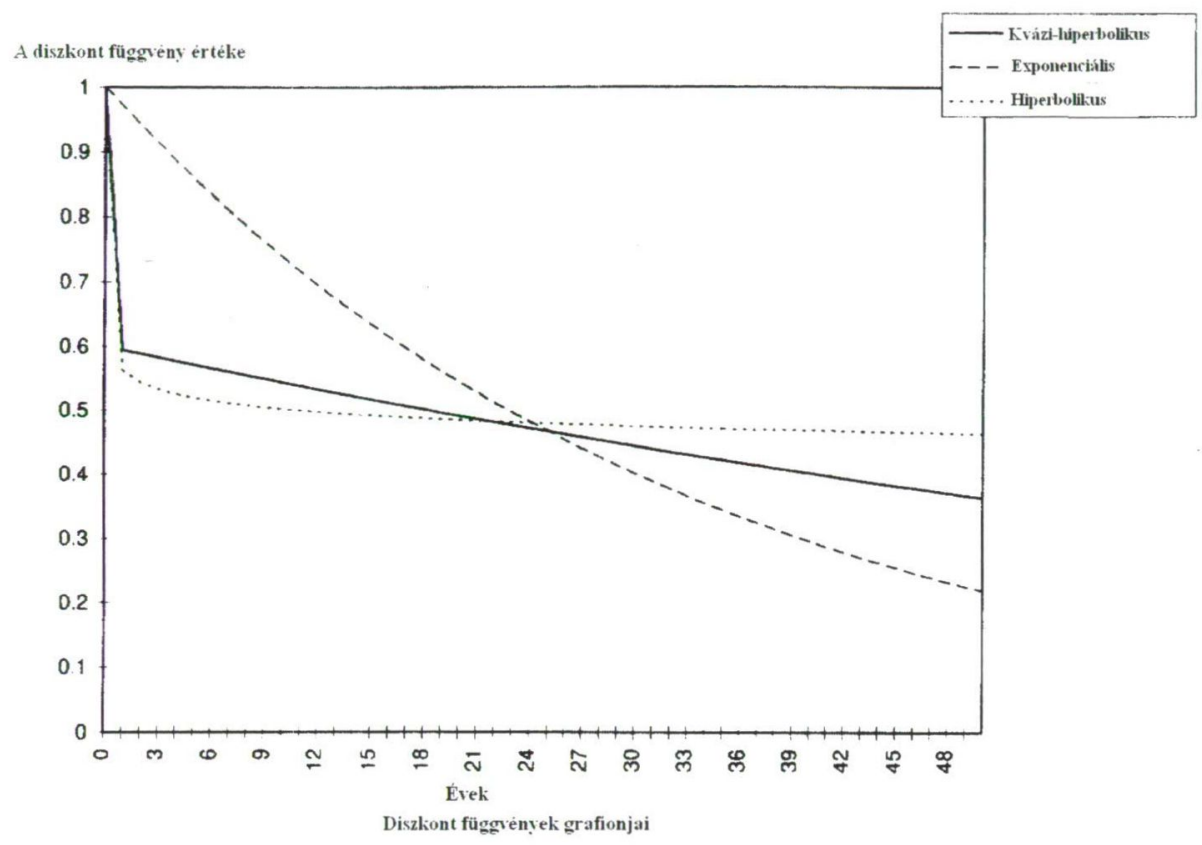

Forrás: Laibson, In: European Economic Review 42 (1998: 864)

\section{A MAGATARTÁS GAZDASÁGTAN GYAKORLATI ALKALMAZÁSA - EGY LEHETSÉGES FELHASZNÁLÁSI TERÜLET: A NYUGDÍJ- ELŐTAKARÉKOSSÁG VIZSGÁLATA}

Ebben a fejezetben a magatartás gazdaságtan - azon belül is a korábban bemutatott diszkontálási modellek - eredményeinek felhasználhatóságát, gyakorlati alkalmazhatóságát, jelentőségét szeretném röviden bemutatni ${ }^{31}$. A nyugdíjcélú megtakarításokkal való társítás indokoltságát két körülmény is alátámasztja:

- tőkés társadalmakban, ezen belül is a fejlett gazdaságokban szinte mindenkit érint az idős korról való anyagi gondoskodás kérdése

- a nyugdíjcélú megtakarítások az emberi életben az egyik leghosszabb távú intertemporális döntés: mennyit hajlandó az egyén ma megtakarítani, más szavakkal megfogalmazva mennyi fogyasztásról mond le egy későbbi időszaki hasznosság fejében.

Barr (2005) és Thornton (2001) is felhívta a figyelmet a megtakarítások és a nyugdíjrendszer kapcsolatára. Ezen kívül még számos tudományos publikáció tanúskodik a téma (hiperbolikus diszkontálás és a hosszú távú megtakarítások) relevanciájáról (Laibson 1996, 1998, Laibson et al. 1998, Normann-Langer 2001,

${ }^{31}$ Lásd bővebben Rabin (1996): Psychology and Economics. University of California, Berkeley. 
Lazaro A. et al. 2002, Diamond-Köszegi 2003, Salanié-Treich 2006, Cremer et al. 2006, Schwarz-Sheshinski 2007, Kumru-Thanopoulos 2008). Abban az esetben, ha többet szeretnénk megtudni a döntéshozók, megtakarítók preferenciáiról, és ezáltal sokkal hatékonyabb, célravezetőbb nyugdíjrendszert akarunk müködtetni, akkor a legfontosabb kérdések, amelyeket tisztázni kell a következőek (SanchezChavez 2008):

- a nyugdíjcélú megtakarítók diszkontált hasznosság függvénye milyen jellegü, ha egyáltalán ki lehet mutatni függvényszerü kapcsolatot (exponenciális, hiperbolikus, kvázi-hiperbolikus), milyen paraméterekkel kalkulálhatunk;

- ha minden más tényezőt változatlannak feltételezünk, akkor mennyi lenne az elegendő megtakarítási szint (idöszakra lebontva a jövedelem arányában), hogy az egyén ne veszítsen nyugdíjas korában az általa megszokott életszínvonalból, fogyasztásából, és hogy az államnak ne kelljen költségvetési kiegészítésekböl fenntartani az időskori inaktív életszakasz fogyasztási nívóját, illetve hogy a mélyszegénységet veszélyét elkerüljék;

- az egyén hogyan viszonyul a közösséghez, milyen közösségi preferenciái vannak;

- az időre vonatkozó inkonzisztencián kívül milyen más anomáliákat fedezhetünk fel a megtakarítóknál;

- A viselkedésbeli anomáliák ismeretében, hogyan alakítsuk ki a nyugdíjrendszer egészét, vagy részét, az egyénnek minél több esélye legyen arra, hogy a megszokott életszínvonalát fenntartsa.

A hosszú távú megtakarítások vizsgálatát a legtöbbször be szokták illeszteni az életpálya elméletbe (life-cycle theory), amelynek kezdete egészen Ramsey és Modigliani-Brumberg munkásságáig nyúlik vissza (Ramsey 1928, ModiglianiBrumberg 1954, Sanchez-Chavez 2008). Az elmélet értelmében az életpálya három részre tagolódik: ifjúkor, aktív kereső kor (gesztációs időszak), időskor vagy inaktív szakasz. A megtakarítások szoros összefüggésben vannak a jövedelemmel és a fogyasztással. Megtakarítás abból a jövedelemrészből képződhet, amelyet nem fogyasztunk el. A felhalmozott tőke és annak hozamai hivatottak arra, hogy az optimális önfinanszírozó, fenntartható nyugdíjrendszer esetén biztosítsa a kieső jövedelmeket az egyén számára. Abban az esetben, ha a neoklasszikus racionalitást tételezzük fel, akkor az életciklusra szóló fogyasztás, és ezáltal a megtakarítás is időben konzisztens (Komamura-Yamada 2006: 30). Más szavakkal megfogalmazva, feltehető, hogy egy adott időpontban kiválasztott fogyasztási (megtakarítási) terv az időben mindig a legjobb választás lesz bármely jövőbeli időpontban. A megtakarításnak - és természetesen a fogyasztásnak is - lehetnek normatív jegyei is, amikor érvényesülhet a racionalitás, de jellemző rá, illetve rájuk a hiperbolikus diszkontálás jegyei is, amelyek az intertemporális döntések anomáliáit írják le.

Angeletos és szerzőtársai (Angeletos G. et al. 2001: 49) négy jellemzőre mutatott rá, hogy mikor alkalmazható a hiperbolikus diszkontálás modellje a megtakarítási viselkedésre: 
1. a hiperbolikus diszkontálással jellemezhető háztartások vagyonukat nem likvid eszközökben tartják annak érdekében, hogy a jövőben a fogyasztási igény ellen bebiztosítsák magukat;

2. a hiperbolikus diszkontálással jellemezhető háztartások magas szintü megújuló adósságállománnyal jellemezhetőek, annak ellenére, hogy a hitelfelvételnek, folyószámlahiteleknek magas a kamatterhe;

3. a hiperbolikus diszkontálással jellemezhető háztartások alacsony likvid vagyonnal rendelkeznek, és képtelenek a fogyasztásukat „kisimítani”. Párhuzam keletkezik a jövedelem és a fogyasztás között;

4. a nyugdíjkorhatár közeledtével ez a kapcsolat kiemelkedővé válik: amikor a munkajövedelem csökken, maga után vonja a likvid vagyon hiánya által generált fogyasztáscsökkenést, és a nem likvid eszközök elvesztését.

Eisenhauer és Ventura (Eisenhauer-Ventura 2006) hasonló következtetéseket vontak le: a hiperbolikus diszkont függvénnyel jellemezhető egyének kevesebbet takarítanak meg, mint exponenciális függvénnyel karakterizálható társaik. Bemutatták továbbá azt is, hogy a nem racionális megtakarítók fix eszközökbe fektetik pénzüket, hogy korlátozzák saját fogyasztásukat. Diamond és Köszegi (Diamond-Köszegi 2003) a fogyasztási minták felvázolásához használta ugyanezt a modellt, és szintén szignifikáns eltéréseket tapasztaltak a hiperbolikus és az exponenciális szereplök között (Sanchez-Chavez 2008).

\section{ZÁRÓ GONDOLATOK}

Írásomban összefoglaló, ismertető jelleggel mutattam be az intertemporális döntéseket, viselkedési mintákat leíró különböző modelleket. Öt ilyen keretrendszert ismertettem, ezek rendre a következőek: neoklasszikus, Loewenstein-Prelec, Harvey, Mazur, Laibson kvázi-hiperbolikus elmélete. Hogy melyik modell illeszkedése, magyarázó ereje jobb, az esetenként, vizsgált területenként eltérő lehet. Konkrét összehasonlítást Lippai mủvében találhatunk (Lippai 2009). A nyugdíjcélú megtakarításokkal vont párhuzam bemutatása kézenfekvő volt: egyrészt a gyakorlati szempontok, az alkalmazhatóság a magatartás gazdaságtan számára is létkérdés, másfelöl globális probléma a nyugdíjrendszerek fenntarthatósága, amelyek egyre inkább a tőkefelhalmozásra épülnek. A nyugdíjcélú megtakarítások fenyegetően alacsony szintjének magyarázata során nem pusztán gazdasági okokat kell keresnünk, hanem pszichés tényezőket is. A gazdasági döntéshozók, nevezzük őket itt nyugdíj előtakarékoskodóknak, racionalitása a kutatások szerint erősen megkérdőjelezhető. Ha feltérképezzük a torzításokat, a hiperbolikus diszkontfüggvény paramétereinek kvantitatív felkutatásával tisztában lehetünk az egyének dinamikus inkonzisztenciájával. Ha ismerjük a torzítás mértékét, akkor a megfelelő eszközök segítségével korrigálhatjuk, befolyásolhatjuk a döntéshozókat. 


\section{IRODALOMJEGYZÉK}

Ainslie G. (1992): Picoeconomics: The strategic interaction of successive motivational states, Cambridge University Press, 1992.

Akerlof G. A. (1991): Procrastination and Obedience. In. American Economic Review, AEA Papers and Proceedings, pp. 1-19. Elektronikus elérhetőség: http://socsci2.ucsd.edu/ aronatas/project/academic/akerlof\%20on\%20procrastination.pdf

Angeletos G. et al. (2001): The Hyperbolic Consumption Model: Calibration, Simulation, and Empirical Evaluation. In. Journal Economic Perspectives. 15(3), pp. 47-68.

Barr N. (2005): Notional Defined Contribution Pensions: Mapping the terrain. In. Holzmann, R. Palmer, E. (editors). Pension Reform through NDCs: Issue and Prospect for Non-Financial Defined Contribution Schemes. Washington D.C.: The World Bank

Cremer H. et al. (2006): Designing a linear pension scheme with forced savings and wage heterogenity. Elektronikus elérhetőség: http://neeo.univ-tlse1.fr/668/1/designing.pdf

Dezső L. - Neszveda G. (2010): Intertemporális döntések magatartásgazdaságtani modellje. BCE, Behavioral Economics Workshop, 2010. 04. 23. Az előadás anyaga PPT formátumban.

Elektronikus elérhetöség:

http://m.blog.hu/be/behavioreconomicsworkshop/BEHAV_WORKSHOP_IntertemMaggazd_04 23-Vegl.ppt

Diamond P. - Köszegi B. (2003): Quasi-hyperbolic discounting and retirement. In. Journal of Public Economics. 87 (2003), pp. 1839-1872.

Eisenhauer J. - Ventura L. (2006): The prevalence of hyperbolic discounting: some European evidence. In. Applied Economics. 38(2006), pp. 1223-1234.

Goldman S. M. (1980): Consistent Plans. In. Review of Economic Studies, XLVII (1980), pp. 533537.

Harvey C. M. (1986): Value Functions for Infinite-Period Planning. In. Management Science 32. p. 1123.

Hámori B. (1998): Érzelemgazdaságtan. A közgazdasági elemzés kiterjesztése. Kossuth Kiadó, Budapest.

Imbrohoroglu A. et al. (2003): Time Inconsistent Preferences and Social Security. In. The Quarterly Journal of Economics. (2003), pp. 745-784.

Koltay G. - Vincze J. (2009): Fogyasztói döntések a viselkedési közgazdaságtan szemszögéböl. In. Közgazdasági Szemle, LVI. évf. 2009. június, pp. 495-525.

Komamura K. - Yamada A. (2008): Evasion of National Pension Contributions and Hyperbolic Time Discounting: Evidence and Rationale for Public Pensions. In. Government Auditing Review. VOLUME15 (March 2008)

Kumru C. S. - Thanopoulos A. C. (2008): Social security and self control preferences. In. Journal of Economic Dynamics \& Control 32 (2008) pp. 757-778.

Laibson D. I. (1996): Hyperbolic discount functions, undersaving, and savings policy. In. Working Paper 5635. National Bureau of Economic Research

Laibson D. I. (1998): Life-cycle consumption and hyperbolic discount functions. In. European Economic Review 42 (1998) pp. 861-871. Elektronikus elérhetőség: https://www.statistica.unipd.it/insegnamenti/temimacro/matdid/Laibson_EER98.pdf

Laibson D. I. et al. (1998): Self-control and Saving for Retirement. In. Brookings Papers on Economic Activity, Vol. 1998. Issue 1.pp. 91- 172.

Lazaro A. et al. (2002): The discounted utility model and social preferences: Some alternative formulations to conventional discounting. In. Journal of Economic Psychology 23 (2002) pp. $317-337$.

Lippai L. (2009): Az intertemporális diszkontálási folyamatok jelentősége a fogyasztói döntésekben. In. Közgazdasági Szemle. LVI. évf. 2009. július-augusztus.

Loewenstein G.-Prelec D. (1992): Anomalies in Intertemporal Choice: Evidence and an Interpretation. In. Quarterly Journal of Economics, 57:2, pp. 573-598.

Mazur J. E. (1987): An adjusting Procedure for Studying Delayed Reinforcement. 
Modigliani F. - Brumberg R. (1954): Utility Analyses and The Consumption Function: An interpretation of Cross Section Data. In. Kurihara, K. (ed.) Post Keynesian Economics. Rutgers University Press.

Noor J. (2009): Hyperbolic discounting and the standard model: Eliciting discount functions. In. Journal of Economic Theory 144 (2009) pp. 2077-2083.

Normann M. - Langer T. (2001): Altervorsorge, Konsumwunsch und mangelnde Selbstdisziplin: Zur Relevanz deskriptiver Theorien für die Gestaltung von Altersvorsorgeprodukten. In. Sonderforschungsbereich 504. No. 01-40. University of Mannheim, Mannheim. Elektronikus elérhetőség: https://ub-madoc.bib.uni-mannheim.de/2801/

Peleg B. - Yaari M. E. (1973): On the existence of a Consistent Course of Action when Tastes are Changing. In. Review of Economic Studies 40. pp. 391-401.

Phelps E. S. - Pollak R. A. (1968): On Second-Best National Saving and Game-Equilibrium Growth. In. Review of Economic Studies, XXXV (1968), pp. 185-99.

Ramsey F. P. (1928): A Mathematical Theory of Saving. In. The Economical Journal 38 (152) pp. 543-549. Elektronikus elérhetőség: http://darp.lse.ac.uk/papersdb/Ramsey_\%28EJ_28\%29.pdf

Salanié F. - Treich N. (2006): Over-savings and hyperbolic discounting. In. European Economic Review 50 (2006) pp. 1557-1570.

Samuelson P. (1937): A Note on the Measurement of Utility. In. Review of Economic Studies, 4(2), pp. 155-161.

Samwick A. A. (1998): Discount rate heterogeneity and social security reform. In. Journal of Developement Economics. Vol. 57. (1998) pp. 117-146.

Sanchez - Chavez E. J. (2007): Retirement Forced Saving in Peru using Hyperbolic Discounting Functions: A Doctoral Research Proposal. In. Journal of Central Cathedra pp. 120-136.

Schelling T. C. (1984): Self-Command in Practice, in Policy, and in a Theory of Rational Choice. In. AEA Papers and Proceedings. 74 (2), pp. 1-11.

Schwarz M. E. - Sheshinski E. (2007): Quasi-hyperbolic discounting and social security systems. In. European Economic Review 51. (2007) pp. 1247-1262. Elektronikus elérhetőség: http://ideas.repec.org/a/eee/eecrev/v51y2007i5p1247-1262.html

Strotz R. (1956): Myopia and Inconsistency in Dynamic Utility Maximization. In. Review of Economic Studies. 23(3), pp. 165-180.

Thaler, R. - Shefrin, H. (1981): An economic theory of self-control. In. Journal of Political Economy, Vol. 89, S. pp. 392-406.

Thornton J. (2001): Age Structure and the personal savings rate in the United States. In. Southern Economic Journal. 68 (1) pp. 166-170.

van der Pol M. - Cairns J. (2002): A comparison of the discounted utility model and hyperbolic discounting models in the case of social and private intertemporal preferences for health. In. Journal of Economic Behavior \& Organization Vol. 49 (2002) pp. 79-96.

Wahlund R. - Gunnarson J. (1996): Mental Discounting and Financial Strategies. In. Journal of Economic Psychology, Vol. 17. No. 6. pp. 709-730.

Zeckhauser R. - Fels S. (1968): Discounting for proximity with perfect and tot al altruism. In. Harvard Institute of Economic Research, Discussion paper 50. 49. 